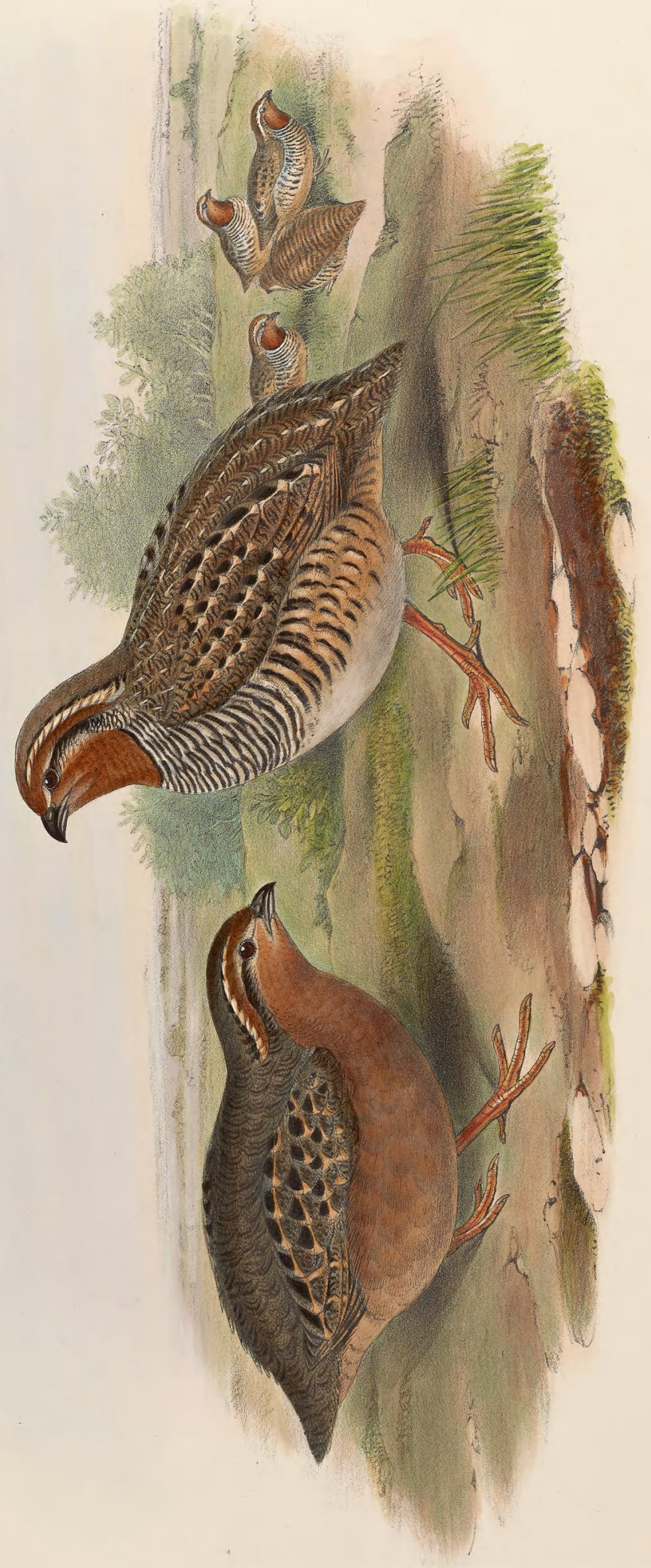

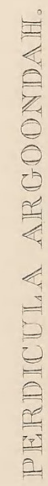




\title{
PERDICULA ARGOONDAH.
}

\author{
A rgoondah Bush-Quail.
}

Coturnix Argoondah, Sykes, Proc. of Comm. of Sci. and Corr. of Zool. Soc., part ii. p. 153.-Id. Trans. Zool. Soc., vol. ii. p. 17, pl. 2.-Burg. in Proc. Zool. Soc., part xxiii. p. 31.-Gray and Mitch. Gen. of Birds, vol. iii. p. 507, Coturnix, sp. 8.-Jerd. Madras Journ. of Lit. and Sci., vol. xii. p. 6.

Perdix rubiginosa, Valenc. ? (Blyth).

Perdicula Argoondah, Blyth, Cat. of Birds in Mus. Asiat. Soc. Calcutta, p. 254, and app. p. 342 (app. to no. 1518). -Id. Ann. and Mag. Nat. Hist., vol. xx. p. 322._Layard, Ann. and Mag. Nat. Hist., 2nd ser. vol. xiv. p. 107

Lauwau Partridge, Lath. Gen. Hist., vol. viii. p. 304 (Blyth).

Geerza, Hind, Blyth.

IT will be seen by the following extract from Colonel Sykes's paper "On the Quails and Hemipodii of India," published in the second volume of the 'Transactions of the Zoological Society of London,' that the remark I have made in my account of Perdicula asiatica, as to the infinite variation in the colouring and markings of the Bush-Quails, is fully borne out by the observations of that gentleman.

"There are so many trifling variations in the markings of the plumage of the upper surface of this bird, that it is difficult to fix upon the exact type. The male is readily distinguished by the numerous transverse narrow black bars upon the breast; but the young males and the females want these bars, and vary so much in the markings on the back, that, with those disposed to manufacture species from plumage alone, the eleven specimens before me, from Dukhan, would furnish at least four new species. The varieties in these eleven specimens consist in the adult male birds being destitute of the black blotches on the upper surface, black bars on the tail, and black tips to the feathers on the back of the neck, but having the tawny bars. One adult male exactly resembles the female, on the upper surface, in the absence of distinct markings, but has a more rufous shade of plumage. A female has faint black bars on the breast. Had these birds come to hand as isolated specimens, they would probably have been considered as distinct species. There is scarcely any difference in the size of the males and females.

"These birds do not frequent cultivated lands, but are found all over Dukhan on the general level of the country, amidst rocks and low bushes; they rise in coveys of from ten to twenty, or more, from under the feet, with a startling suddenness and bustle; and the young sportsman is perplexed in selecting his bird. They are gregarious and, I infer, polygamous, as I never saw them solitary or in pairs. Flesh perfectly white.

"This is the species used for Quail-fights by the natives, and not Coturnix dactylisonans, or C. textilis."

In the 'Proceedings of the Zoological Society,' Colonel Sykes says that this bird is also found "on the most elevated table-lands and slopes of the mountains, amidst reeds and grass; specimens procured at 4000 feet above the sea."

"This pretty little Quail," says Captain Burgess, " is an inhabitant of stony hills and bushy sides of streams and nullahs. It lives in bevies, and is to be met with in company with the grey and black-breasted Quails. It breeds generally during the months of November and December; but I have had its eggs brought to me as late as March, and have procured a young bird, well fledged, as early as the 20th of November. It does not, I believe, lay more than four eggs, as on three different occasions I have had that number brought to me, and on a fourth, four young ones, just fledged, when out Quail-shooting. They were covered with down, and had the appearance of being powdered. The eggs are of a pale buff colour, $1 \frac{1}{10}$ th inch in length, by $\frac{8}{10}$ ths of an inch in width."

Mr. Layard, speaking of the bird as seen by him in Ceylon, says, "I have only seen one pair of these elegant little Partridges; they were caught alive at Cotta, near Colombo, in Ceylon. I have an egg which can only belong to this bird, also found in the same locality; axis 12 lines, diam. 9 lines. It precisely resembles a diminutive Partridge egg."

The male has the forehead, a broad stripe above the eye, and the throat-gorget rich reddish chestnut; a line along the lores of buffy white; above the red superciliary stripe a second stripe of buffy white, bordered 
posteriorly with blotches of black; nape pale brown; all the upper surface pale reddish brown, transversely crossed by numerous irregular bars of blackish brown, and with a small spatulate mark of buff in the centre of the tip of many of the feathers; wing-coverts and scapularies similarly marked, but the buff marks are accompanied by a blotch of black, which is of large size on the feathers nearest the body; primaries brown, barred on the outer web with deep buff; tail barred with deep buff and black; breast and flanks barred alternately with greyish white and black; on the flanks these bars increase in size, and the greyish white is washed with buff; centre of the abdomen buff; irides reddish fuscous; bill black; legs and toes reddish.

The female is similarly marked, but the gorget merges into the vinaceous red of the under surface; and the upper surface is of a darker hue, and destitute of the small spatulate markings of buff.

Another specimen, also said to be a female, has the entire plumage pale vinaceous brown, with the wings and tail minutely and almost indistinctly freckled with brown, in the form of irregular bars.

My figures are supposed to represent the two sexes as above described; but I must observe that the figure and description of the female was taken from a specimen unusually dark in colour, while in most instances the specimens sent to this country as examples of the feminine sex are more uniform, like the second female above described.

The Plate represents the two sexes of the natural size, and a reduced group in various states of colouring. 


\section{$2 \mathrm{BHL}$ Biodiversity Heritage Library}

Gould, John. 1863. "Argoondah Bush-Quail, Perdicula argoondah [PI. 5]." The Birds of Asia 7(XV), -. https://doi.org/10.5962/p.323425.

View This Item Online: https://www.biodiversitylibrary.org/item/122491

DOI: https://doi.org/10.5962/p.323425

Permalink: https://www.biodiversitylibrary.org/partpdf/323425

\section{Holding Institution}

Smithsonian Libraries

\section{Sponsored by}

Smithsonian Institution Libraries

\section{Copyright \& Reuse}

Copyright Status: Not in copyright

This document was created from content at the Biodiversity Heritage Library, the world's largest open access digital library for biodiversity literature and archives. Visit BHL at https://www.biodiversitylibrary.org. 